\title{
Influences of High-Sulphur Fly Ash on the Properties of Lightweight Cement-Treated Materials Subjected to Sulphate Corrosion
}

\author{
Xiaoyuan Wang ${ }^{1}$, Pengju Han ${ }^{1, *}$, Xiaoqiang Dong ${ }^{1, *}$, Xiangyu $\mathrm{Li}^{1}{ }^{1}$, Xiaohong Bai ${ }^{1}$, Bin $\mathrm{He}^{1,2}$, \\ Shiwei Niu ${ }^{1}$ and Funan Sun ${ }^{1}$ \\ 1 College of Civil Engineering, Taiyuan University of Technology, West Yingze Street 79, Taiyuan 030024, \\ China; wangxy765914870@gmail.com (X.W.); lixiangyu@tyut.edu.cn (X.L.); bxhong@tyut.edu.cn (X.B.); \\ hebin@tyut.edu.cn (B.H.); 18236110213@163.com (S.N.); Sunfn1008@163.com (F.S.) \\ 2 Key Laboratory of Geotechnical and Underground Engineering of Ministry of Education, \\ Tongii University, Shanghai 200092, China \\ * Correspondence: 13834569544@163.com (P.H.); dongxiaoqiang@126.com (X.D.); \\ Tel.: +86-138-3456-9544 (P.H.); +86-133-3351-5050 (X.D.)
}

Received: 15 May 2020; Accepted: 27 July 2020; Published: 29 July 2020

\begin{abstract}
In this study, the effects of high-sulphur fly ash on the properties of lightweight cement-treated materials (LCMs) immersed in sodium sulphate solutions were studied. The unconfined compressive strength of LCMs corroded by sulphate was tested. The microscopic properties were characterised by X-ray diffraction (XRD), electrochemical impedance spectroscopy (EIS), and scanning electron microscopy (SEM). The results show that high-sulphur fly ash has an adverse effect on the structural strength of LCMs after corrosion, but when the content of fly ash is less than $75 \%$, the effect of fly ash on the strength is small. A small amount of high-sulphur fly ash can improve the density of the material structure; the internal pore structure of LCMs provides space for the growth of ettringite and other corrosive substances and relieves the expansion pressure. LCMs mixed with high-sulphur fly ash have a certain resistance to sodium sulphate corrosion.
\end{abstract}

Keywords: lightweight cement-treated materials; high-sulphur fly ash; sulphate corrosion; unconfined compressive strength; X-ray diffraction; electrochemical impedance spectroscopy; scanning electron microscopy

\section{Introduction}

Fly ash has the advantages of being light weight, of low compressibility, and having a rapid rate of consolidation. Taking fly ash as the material for roadbed paving can not only save energy and reduce emissions, but also reduce the pollution caused thereby to some extent [1-5]; however, when the sulphur content of fly ash is high, the fly ash reacts with lime and hardens. Volumetric expansion occurs at the later stage of strength development, which leads to the cracking, arching, and uneven settlement of pavement bases [6-10]. Therefore, it is necessary for geotechnical engineers to find a treatment method using high-sulphur fly ash for roadbed paving. In the present research, high-sulphur fly ash, cement, and a dense foam were mixed to form a light porous material (called lightweight cement-treated material), to overcome the adverse effects encountered in the application of high-sulphur fly ash.

Lightweight cement-treated materials (LCMs) are a filling material consisting of cement, low-liquid-limit soil, water, and bubbles. Its density and strength can be freely regulated by changing the bubble content [11-15]. Due to its adjustable density and workability, LCMs are widely used in foundation treatment, backfill grouting, and slope reinforcement [16-18]. Especially in soft soil foundation construction, LCMs are often used as a more economical and reasonable treatment method. 
Kadela [19] showed the potential of a foamed concrete layer as the base of a pavement structure. As a typical pozzolanic material, fly ash can improve the hydration and compactness of a material's microstructure when it is used in cement-treated soil systems [20-25]. Most importantly, the expansive stress caused by the late hydration of high-sulphur fly ash can be buffered by the numerous pores in cement-treated materials. Studying the effect of high-sulphur fly ash on LCMs is not only expected to improve some properties of LCMs but also provide an economical and safe treatment method for high-sulphur fly ash.

Studies have shown that the materials with the properties of volcanic ash can be used with cementitious materials, such as cement. Contrafatto [26] showed three trends in mixes of Mount Etna volcanic ash and cement materials; among them, the mechanical and thermal properties of the mixture are good [27] when Etna volcanic ash is applied to insulating mortar and light mortar. Xiao et al. [28], Pourkhorshidi et al. [29], Celik et al. [30], and Zhao et al. [31] found that the curing performance of mixed mortar can be improved to a certain extent when volcanic ash is used as a partial replacement for Portland cement. Kupwade-Patil [32] showed the effectiveness of volcanic ash in replacing part of the cement. Kalakada [33] further concluded that the best ratio of pozzolanic ash to cement was $30 \%$, at which the strength and impermeability of concrete products were improved. In recent years, fly ash, used as a pozzolanic material, has attracted much research interest. For example, the durability of fly ash concrete has been studied [34] and it was found [35] that pore distribution directly affects the performance of LCMs, the addition of fly ash can increase the degree of bubble coalescence, and the spherical structure of fly ash can make the bubbles move and coalesce more easily. In addition, the presence of fly ash also improves the workability, mechanical properties, and freeze-thaw resistance of such materials [36-41]. The partial replacement of cement and sand with fly ash can also reduce material shrinkage [42]. Compared with LCMs without fly ash, samples containing fly ash have better thermal insulation $[43,44]$; however, when using fly ash with a high sulphur content as an admixture, there is no relevant research to prove that LCMs can still meet all the engineering performance criteria, especially when LCMs are used in some areas where there is a large amount of sulphate present. Due to the large amount of sulphide in LCMs, it is not known whether an external high-sulphur environment will aggravate the degradation of LCMs; therefore, the ability to resist sulphate corrosion must be studied.

In this study, the mechanical properties and durability of LCMs with different high-sulphur fly ash contents were investigated. The samples were immersed in sodium sulphate solution of different concentrations for curing, then unconfined compressive strength, $X$-ray diffraction (XRD), electrochemical impedance spectroscopy (EIS), and scanning electronic microscopy (SEM) tests were conducted.

\section{Materials}

\subsection{Test Materials}

The main materials needed in this experimental include: cement, high-sulphur fly ash, foaming agent, and water.

The cement is a $42.5 \mathrm{R}$ ordinary Portland cement produced by Taiyuan Lionhead Cement Co. Lt (China). Table 1 shows the chemical compositions of the cement measured by an X-ray fluorescence test (by percentage).

Table 1. Chemical composition of the cement.

\begin{tabular}{cccccccccc}
\hline Component & $\mathrm{CaO}$ & $\mathrm{SiO}_{2}$ & $\mathrm{Al}_{2} \mathbf{O}_{3}$ & $\mathrm{Fe}_{\mathbf{2}} \mathrm{O}_{3}$ & $\mathbf{M g O}$ & $\mathrm{SO}_{3}$ & $\mathbf{N a}_{\mathbf{2}} \mathbf{O}$ & $\mathbf{K}_{2} \mathbf{O}$ & Loss \\
\hline Content (by mass \%) & 66.35 & 18.81 & 5.86 & 3.34 & 1.04 & 2.53 & 0.31 & 0.41 & 0.45 \\
\hline
\end{tabular}


The high-sulphur fly ash used in this experimental was produced by Taiyuan No.1 Thermal Power Plant. The particle distribution curve of fly ash was measured by a densitometer, as shown in Figure 1. The fly ash particles are concentrated in the range $0.01-0.1 \mathrm{~mm}$.

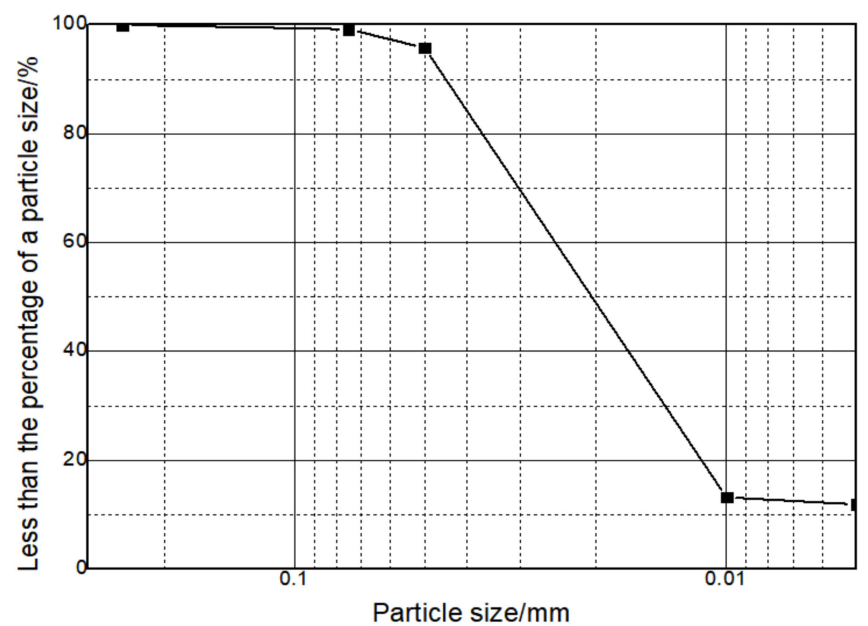

Figure 1. Particle size distribution curve of fly ash.

The main properties of high-sulphur fly ash are shown in Table 2 (by percentage). The test method is based on "Fly ash used for cement and concrete GB/T1596-2017" (in Chinese).

Table 2. Properties of high-sulphur fly ash.

\begin{tabular}{cccccc}
\hline Fineness & $\begin{array}{c}\text { Water Requirement } \\
\text { Ratio }\end{array}$ & $\begin{array}{c}\text { Loss on } \\
\text { Ignition }\end{array}$ & $\begin{array}{c}\text { Sulphur } \\
\text { Trioxide }\end{array}$ & $\begin{array}{c}\text { Water } \\
\text { Content }\end{array}$ & $\begin{array}{c}\text { Free Calcium } \\
\text { Oxide }\end{array}$ \\
\hline 10.2 & 107 & 5.21 & 6.99 & 0.32 & 2.45 \\
\hline
\end{tabular}

Table 3 shows the chemical compositions of high-sulphur fly ash measured by X-ray fluorescence (by percentage).

Table 3. Chemical composition of high-sulphur fly ash.

\begin{tabular}{ccccccccc}
\hline Component & $\mathrm{CaO}$ & $\mathrm{SiO}_{2}$ & $\mathrm{Al}_{2} \mathrm{O}_{3}$ & $\mathrm{Fe}_{\mathbf{2}} \mathrm{O}_{3}$ & $\mathrm{MgO}$ & $\mathrm{SO}_{3}$ & $\mathrm{f}-\mathrm{CaO}$ & Loss \\
\hline Content (by mass \%) & 23.57 & 34.6 & 18.57 & 7.66 & 3.41 & 6.99 & 2.45 & 2.75 \\
\hline
\end{tabular}

The foaming agent is a YS compound foaming agent produced by Nanjing Daye Construction Materials Co (China). It is a composite foaming agent which is composed of an anionic surfactant and animal protein. In the experiment, the mixing ratio of the foaming agent and water is 1:40 (by mass). The density after foaming is $37.5 \mathrm{~kg} / \mathrm{m}^{3}$.

\subsection{Test Preparation}

In this test, the proportion of cement was taken with reference to "Technical specification for foamed mixture lightweight soil filling engineering JGJ/T341-2014" (in Chinese). The single factor method is adopted for the mix design. The total amounts of cement, high-sulphur fly ash, foam, and water remain unchanged, and only the ratio of cement and high-sulphur fly ash is adjusted. The proportion of fly ash in the material is $50 \%, 66.7 \%, 75 \%$, and $80 \%$, respectively $(1: 1,1: 2,1: 3$, and $1: 4)$. The compositions by mass of the different mixtures are displayed in Table 4.

According to the customised mix design, we weighed the corresponding amounts of cement, high-sulphur fly ash, and early-strength-gain agent, poured them into a mixer and stirred them for 
1 min until homogeneous, then added the corresponding quantity of water and continued to mix for five minutes. At the same time, the foam was added to the mixture and fully mixed, then the concrete was poured into a mould to form specimens measuring $70 \times 70 \times 70 \mathrm{~mm}$. The samples were cured in water and $5 \%, 10 \%$, and $15 \%$ (by mass) sodium sulphate solution for 28 days, respectively. The curing temperature was $20 \pm 2{ }^{\circ} \mathrm{C}$.

Table 4. Mix proportions.

\begin{tabular}{|c|c|c|c|c|c|c|}
\hline Number & $\begin{array}{l}\text { Cement } \\
\left(\mathrm{kg} / \mathrm{m}^{3}\right)\end{array}$ & $\begin{array}{l}\text { High-Sulphur } \\
\text { Fly Ash }\left(\mathrm{kg} / \mathrm{m}^{3}\right)\end{array}$ & $\begin{array}{c}\text { Water } \\
\left(\mathrm{kg} / \mathrm{m}^{3}\right)\end{array}$ & $\begin{array}{l}\text { Early Strength } \\
\text { Agent }\left(\mathrm{kg} / \mathrm{m}^{3}\right)\end{array}$ & $\begin{array}{l}\text { Foam } \\
\left(\mathrm{L} / \mathrm{m}^{3}\right)\end{array}$ & $\begin{array}{l}\text { Dry Density of } \\
\text { Mixture }\left(\mathrm{kg} / \mathrm{m}^{3}\right)\end{array}$ \\
\hline A1-1 & 465 & 465 & 650 & 18.6 & 1200 & 816 \\
\hline A1-2 & 310 & 620 & 650 & 18.6 & 1200 & 874 \\
\hline A1-3 & 235 & 695 & 650 & 18.6 & 1200 & 860 \\
\hline A1-4 & 190 & 740 & 650 & 18.6 & 1200 & 758 \\
\hline
\end{tabular}

\subsection{Test Method}

After 28 days of curing, the samples were taken out and the surface was dried. The unconfined compressive strength was measured by a WDW-100 microcomputer-controlled electronic universal testing machine. The average compressive strength of three replicate samples was taken as indicative of the test result.

The XRD diffraction pattern tester was a LabX XRD-6000 system, which was used to test the crystal substances in the samples. The type of anode used for XRD is a $\mathrm{Cu}$ anode. Firstly, the samples were ground into fine powder and passed through 325-mesh sieves. The sample powder was made into a very flat test piece and then scanned at a step length of $0.02^{\circ}$. The scanning range was $5^{\circ}$ to $50^{\circ}$.

The electrochemical impedance spectroscopy relied on a Coster CS350 electrochemical workstation system. The sample size of the LCMs ring knife was $\Phi 79.8 \times 20 \mathrm{~mm}$, and copper sheets of the same diameter were placed to cover the surface of the ring knife for use as electrodes. The device was connected to the electrochemical workstation by two wires extending from the copper sheet (Figure 2). The amplitude of the AC sinusoidal signal was $10 \mathrm{mV}$ and the test frequency was in the range of $10^{-2}-10^{5} \mathrm{~Hz}$.

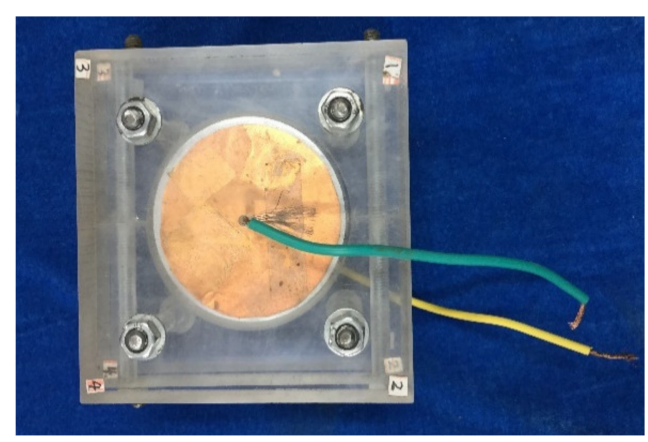

Figure 2. Electrochemical impedance spectroscopy measuring device.

The microstructure of the cemented soil was studied using a TM-3000 scanning electron microscope. The specimen was measured $20 \times 20 \times 5 \mathrm{~mm}$. To ensure its electrical conductivity, the surface of the samples was plated with a thin layer of gold in vacuum.

\section{Results and Discussion}

\subsection{Mechanical Properties of LCMs under Sodium Sulphate Corrosion}

After 28 days of curing in $\mathrm{Na}_{2} \mathrm{SO}_{4}$ solution of different concentrations, the appearance of LCMs with high-sulphur fly ash contents of $50 \%, 66.7 \%, 75 \%, 80 \%(1: 1,1: 2,1: 3,1: 4)$ is shown in Figure 3. 
Each group of pictures shows the appearance of specimens when cured in water and 5\%,10\%, and $15 \%$ sodium sulphate solution.

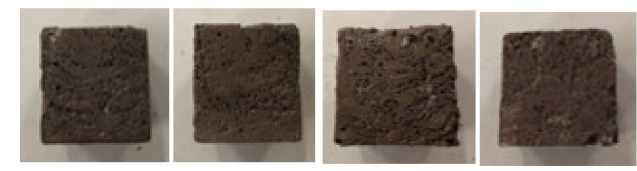

(a)

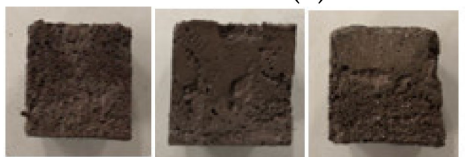

(c)

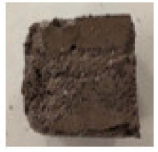

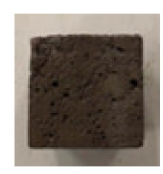

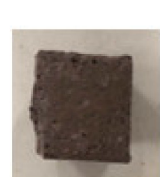

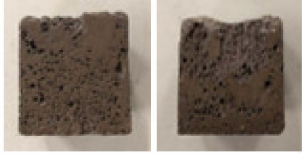

(b)

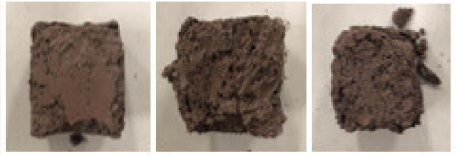

(d)

Figure 3. Corrosion morphology. (a) 50\% high-sulphur fly ash, (b) 66.7\% high-sulphur fly ash, (c) $75 \%$ high-sulphur fly ash, (d) 80\% high-sulphur fly ash.

The appearance of specimens with $50 \%$ high-sulphur fly ash under different environmental curing conditions changes little, and there is no obvious pitting seen on the surface, suggesting a good integrity. At $66.7 \%$ high-sulphur fly ash content, the specimens did not crack, but with the increase in the sodium sulphate concentration, the surface of the specimens gradually became rougher, and the edge of the specimens fragmented. At 75\% high-sulphur fly ash, the specimens show different degrees of damage. With the increase in the concentration of sodium sulphate, the surface of the specimens exhibited small cracks, accompanied by the precipitation of white paste substances and even the corrosion and exfoliation of the epidermis. When the content of high-sulphur fly ash increases to $80 \%$, the specimens remain intact only under water curing.

The unconfined compressive strength of specimens cured in different environments is shown in Figure 4; the unconfined compressive strength of LCMs has certain regularity with the change in fly ash content. The unconfined compressive strength of the specimens decreased the with increasing fly ash content. Among them, in low-concentration sodium sulphate environments ( $0 \%$ and $5 \%$ ), the change in the strength of the samples is small when the fly ash content is less than $75 \%$, and the strength decreases significantly when the content is higher than $75 \%$; for the high-concentration sodium sulphate environments $(10 \%$ and $15 \%)$, the strength of the specimens always decreased rapidly.

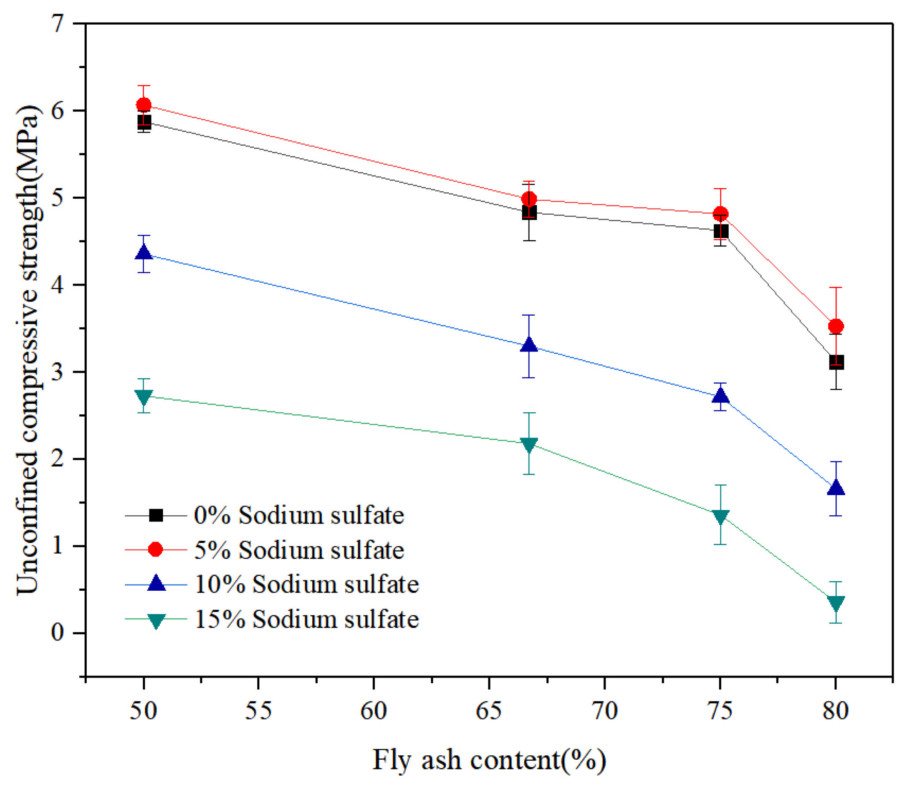

Figure 4. Effect of a high-sulphur fly ash content on the compressive strength under different curing environments. 
The change in specimen strength with the fly ash content results from the change in the content of the cementing material, which plays a connecting role between the components; when the material is hydrated, the formation of $\mathrm{CH}$ causes the environment to be alkaline. These substances surround the active substances present in high-sulphur fly ash, and exchange ions through the water membrane, which causes the pozzolanic effect. Pozzolanic products such as C-S-H and CAH are produced; these bind the particles together through cementation to strengthen the structure. In addition, the fly ash particles are very small. In the manufacturing process of specimens, the fly ash particles readily play the role of filler within the micro-voids in the material, and also play a certain role in strengthening it; therefore, the strength decreases slowly at low contents of high-sulphur fly ash. With the increase in the high-sulphur fly ash content, the activity of the active substances therein is not fully stimulated, and cannot continue to cause the development of the strength of the specimens in this regard; the strength of such specimens is mainly provided by the cementing action of the hydration product C-S-H. The strength of LCMs is affected by the decrease in the cement content. The contribution of fly ash to the strength is lower than that of cement. The compressive strength of the specimens decreases with the increasing fly ash content, consistent with the published data [45,46].

Figure 5 shows the changes in specimen strength with the concentration of sodium sulphate: under the erosive action of sodium sulphate, the strength first increases, then decreases with the increasing concentration of sodium sulphate. The peak strength was found when cured in a $5 \%$ sodium sulphate solution.

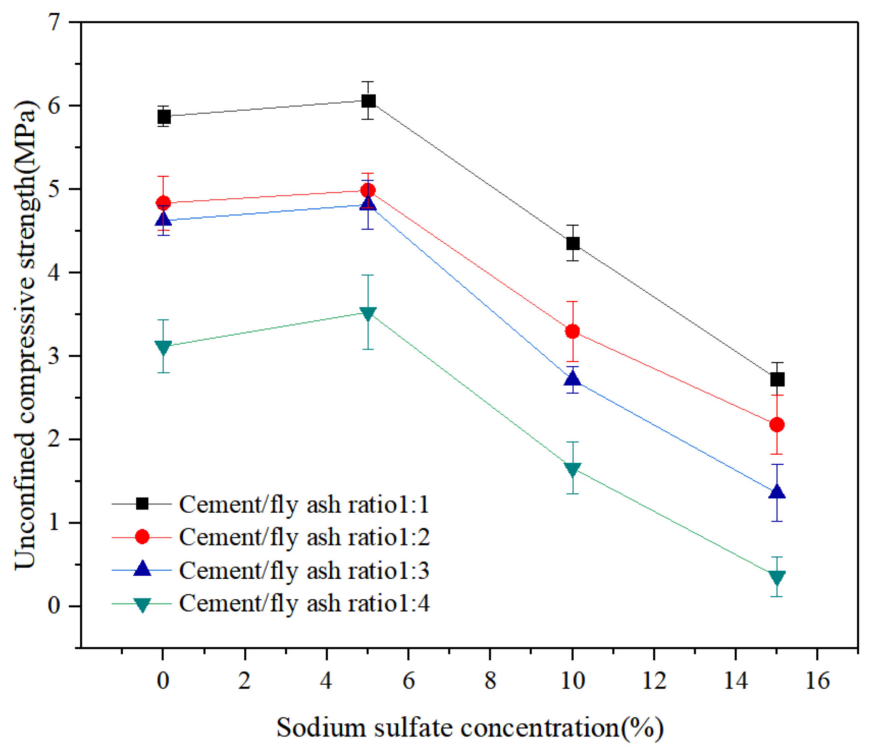

Figure 5. Effect of the sodium sulphate concentration on the compressive strength of the specimens with different high-sulphur fly ash contents.

The effect of sodium sulphate on LCMs is mainly attributed to the chemical action of sulphate ions on the hydration products of materials. When sulphate ions penetrate the matrix, they will react with the hydration products and form ettringite (AFt), which swells and absorbs water during its growth; this produces hoop tension on the pore wall, and leads to structural changes. When the amount of corrosion products is small, the corrosion products will increase the strength of the material while filling the original pores. In Figure 5, when the concentration of sodium sulphate is 5\%, the strength of the specimens will be increased (albeit only slightly). On the one hand, the effects of ettringite and other corrosion products on the strength of LCMs are proved; on the other, the increase in strength also indicates that the artificial cellular pores in LCMs have a certain tolerance for the generation of corrosion products. For LCMs, containing many bubbles, AFt crystal occupied the volume of pores in its growth process due to its porous nature, resulting in limited expansion stress during the growth of the crystalline phase. Moreover, the presence of numerous pores in the LCMs also played a buffer 
role mitigating the swelling of the crystals; therefore, when the sodium sulphate concentration is low, LCMs can reduce the damage caused by ettringite, and AFt crystals can fill pores as an effective structural component of LCMs, promoting its strength to a certain extent. This is why the strength increases when the sodium sulphate concentration is $5 \%$. As the concentration of sodium sulphate was increased, the rate of growth of the ettringite was accelerated. The original pore volume can no longer contain the growth of the ettringite, which eventually leads to structural damage and a reduction in strength. The test results show that LCMs with high-sulphur fly ash can resist the corrosion of sodium sulphate with a concentration not exceeding $5 \%$.

\subsection{X-ray Diffraction Analysis}

It was confirmed [47-49] that the destruction of cement materials caused by sulphate ions is mainly due to the chemical reaction of sulphate ions and hydration products, as shown in Equations (1)-(3).

$$
\begin{gathered}
3 \mathrm{CaO} \cdot \mathrm{Al}_{2} \mathrm{O}_{3}+3 \mathrm{Ca}^{2+}+3 \mathrm{SO}_{4}{ }^{2-}+32 \mathrm{H}_{2} \mathrm{O} \rightarrow 3 \mathrm{CaO} \cdot \mathrm{Al}_{2} \mathrm{O}_{3} \cdot 3 \mathrm{CaSO}_{4} \cdot 32 \mathrm{H}_{2} \mathrm{O} \\
3 \mathrm{CaO} \cdot \mathrm{Al}_{2} \mathrm{O}_{3} \cdot \mathrm{Ca}(\mathrm{OH})_{2} \cdot x \mathrm{H}_{2} \mathrm{O}+2 \mathrm{Ca}^{2+}+3 \mathrm{SO}_{4}{ }^{2-}+(31-x) \mathrm{H}_{2} \mathrm{O} \\
\rightarrow 3 \mathrm{CaO} \cdot \mathrm{Al}_{2} \mathrm{O}_{3} \cdot 3 \mathrm{CaSO}_{4} \cdot 32 \mathrm{H}_{2} \mathrm{O}+2 \mathrm{OH}^{-} \\
3 \mathrm{CaO} \cdot \mathrm{Al}_{2} \mathrm{O}_{3} \cdot \mathrm{CaSO}_{4} \cdot x \mathrm{H}_{2} \mathrm{O}+2 \mathrm{Ca}^{2+}+2 \mathrm{SO}_{4}{ }^{2-}+(32-x) \mathrm{H}_{2} \mathrm{O} \\
\rightarrow 3 \mathrm{CaO} \cdot \mathrm{Al}_{2} \mathrm{O}_{3} \cdot 3 \mathrm{CaSO}_{4} \cdot 32 \mathrm{H}_{2} \mathrm{O}
\end{gathered}
$$

When the concentration of sulphate ions is low, the free sulphate ions in the pore water react with calcium aluminate and its hydration products to form acicular ettringite crystals. With the growth of ettringite crystals, the material structure is destroyed. When the concentration of sulphate ions is high, the corrosion induced by sulphate ions will also lead to the production of gypsum.

Figure 6 shows the XRD pattern of high-sulphur fly ash at a 75\% (1:3) content. It can be seen that the XRD pattern of materials under different environments exhibits certain similarities and differences; in the four groups of diffraction patterns, some conventional hydrated substances such as $\mathrm{SiO}_{2}$ and $\mathrm{CaCO}_{3}$ appeared, and the diffraction peaks of iron oxides appeared in the figure due to the presence of high-sulphur fly ash. The characteristic peak of ettringite in the diffraction pattern of sodium sulphate corrosion specimens is obvious, but it is not found in that for water-cured specimens, evincing the corrosive effect of sulphate ions on LCMs. Moreover, the diffraction peaks of gypsum crystals in the $10 \%$ and $15 \%$ samples are stronger than those in the 5\% samples. According to Biczok [50], when the sulphate concentration is low, the main corrosion product of cement is AFt. When the sulphate concentration is high, the corrosion product is crystalline gypsum crystal. When the sulphate concentration is between the two, the corrosion product contains both, which is consistent with the diffraction peak pertaining to gypsum at higher concentrations of sodium sulphate in Figure 6 . Haufe et al. characterised the entry of sulphate in concrete by XRD, and the research showed that the existence of gypsum crystals is controlled by the concentration of sulphate ions; the results $[51,52]$ support the correctness of this research.

Calcium sulphate hemihydrate was found in four environments. A preliminary analysis showed that this substance was generated by the heating and dehydration of the sample during the XRD sample preparation. When calcium sulphate dihydrate is heated, the bound water in the crystal is lost upon heating, thus forming calcium sulphate hemihydrate. Similarly, the carbonisation of $\mathrm{CH}$ was accelerated by the increase in temperature in the heating process of the sample, which resulted in no diffraction peak arising from $\mathrm{CH}$ being present in the diffraction pattern. 


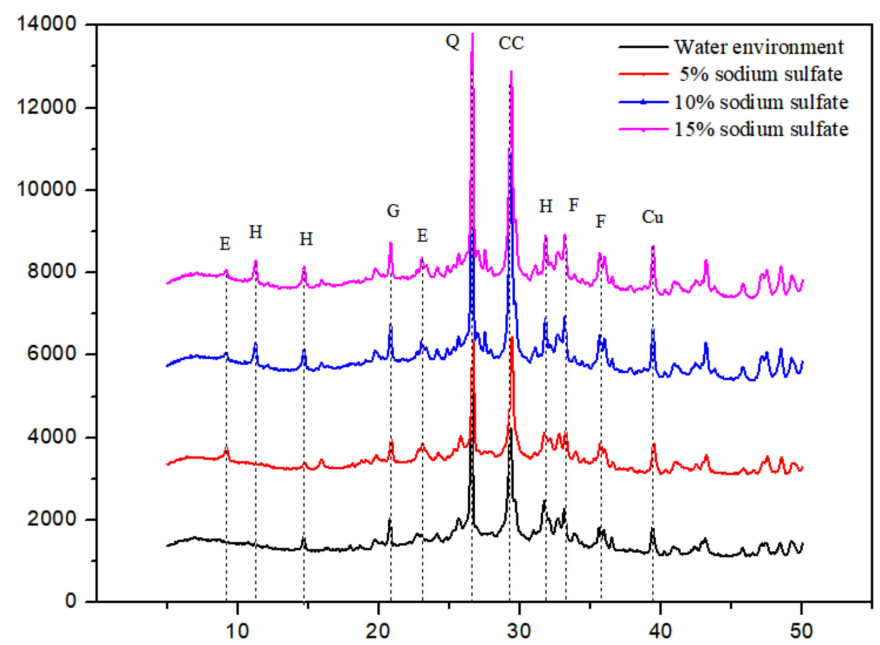

Figure 6. XRD patterns under a 75\% high-sulphur fly ash content. E: Ettringite; H: Calcium sulphate hemihydrate; G: Gypsum; Q: Quartz; CC: Calcite.

\subsection{Electrochemical Impedance Spectroscopy Analysis}

For cement-based materials, the internal structure is more complex than the general electrochemical system, which is composed of solid, liquid and gas phases [53-56]. Generally, the conductive path in cement-treated soil can be divided into three types, as shown in Figure 7.

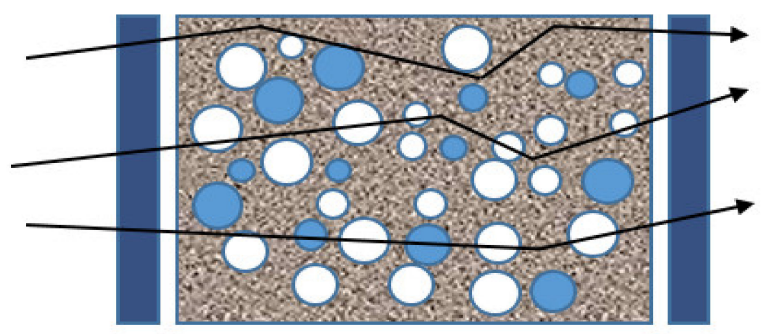

Figure 7. Conductive path.

The first kind of conductive path exists only in solids. Because of the insulation of the material itself, the impedance in the circuit is mainly provided by the solution resistance of the surrounding micro-pore; the second conductive path exists between solids and pores. For cement-based materials, many free charges are gathered in the C-S-H gel, which leads to the formation of capacitance under the action of alternating current. The impedance in the circuit is supplied by the transfer resistance inside the material and the capacitative reactance generated by the pore capacitance; the third conduction path is formed by the interface between the solid medium, the pores, and the pore water. Along this path, ions in the pore fluid will enter the diffusion zone at the solid liquid interface through ion exchange, and diffusion impedance is generated in the process of ion diffusion; The impedance in the circuit is provided by the pore solution resistance, the transfer resistance inside the material, and the diffusion impedance. In addition, under the three paths all ion exchange occurs at the electrode material interface, so it is necessary to consider the impedance at the electrode; the equivalent circuit is shown in Figure 8. 
Rs Pore solution resistance

$C_{1} \quad$ Pore capacitance

$R_{\mathrm{ct} 1} \quad$ Material ion transfer resistance

$W_{1} \quad$ Diffusion impedance of pore solution

$C_{2}$ Dual capacitance on the electrode/material surface

$R_{\mathrm{ct} 2} \quad$ Surface ion transfer resistance of electrode plate

$W_{2} \quad$ Diffusion impedance at the electrode plate

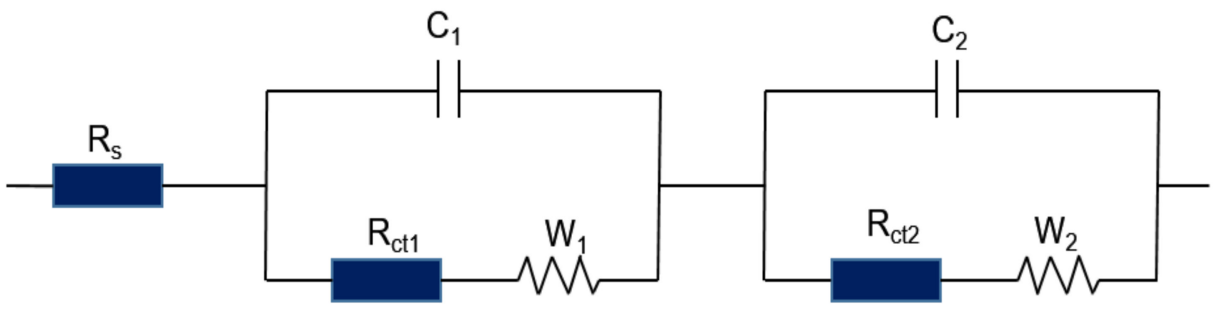

Figure 8. Equivalent circuit.

The Faraday impedance in the equivalent circuit is given by Equations (4)-(7):

$$
\begin{aligned}
& Z_{F 1}=R_{\mathrm{ct} 1}+W_{1} \\
& Z_{F 2}=R_{\mathrm{ct} 2}+W_{2} \\
& W_{1}=\sigma_{1} \omega^{-\frac{1}{2}(1-j)} \\
& W_{2}=\sigma_{2} \omega^{-\frac{1}{2}(1-j)}
\end{aligned}
$$

where $\sigma$ is the impedance coefficient and $\omega$ is the angular frequency.

For the electrochemical equivalent circuit mentioned above, the total impedance expression is given by Equation (8):

$$
Z=R_{\mathrm{S}}+\frac{Z_{F 1}}{1+j \omega Z_{F 1} C_{1}}+\frac{Z_{F 2}}{1+j \omega Z_{F 2} C_{2}}
$$

The real part and imaginary part are given by Equations (9) and (10), respectively.

$$
\begin{aligned}
Z^{\prime}= & R_{\mathrm{s}}+\frac{R_{\mathrm{ct} 1}+\sigma_{1} \omega^{-0.5}}{\left(1+\omega^{0.5} \sigma_{1} C_{1}\right)^{2}+\omega^{2} C_{1}^{2}{ }^{2}\left(R_{\mathrm{ct} 1}+\sigma_{1} \omega^{-0.5}\right)^{2}} \\
& +\frac{R_{\mathrm{c} 2}+\sigma_{2} \omega^{-0.5}}{\left(1+\omega^{0.5} \sigma_{2} C_{2}\right)^{2}+\omega^{2} C_{2}{ }^{2}\left(R_{\mathrm{ct} 2}+\sigma_{2} \omega^{-0.5}\right)^{2}} \\
Z^{\prime \prime}= & j\left[\frac{\omega R_{\mathrm{ct} 1}{ }^{2} C_{1}+2 C_{1} \sigma_{1}{ }^{2} R_{\mathrm{ct} 1} \omega^{0.5}+2 \sigma_{1}{ }^{2} C_{1}+\sigma_{1} \omega^{0.5}}{\left(1+\omega^{0.5} \sigma_{1} C_{1}\right)^{2}+\omega^{2} C_{1}{ }^{2}\left(R_{\mathrm{ct} 1}+\sigma_{1} \omega^{-0.5}\right)^{2}}\right] \\
& +\frac{\omega R_{\mathrm{ct} 2}{ }^{2} C_{2}+2 C_{2} \sigma_{2}{ }^{2} R_{\mathrm{ct} 2} \omega^{0.5}+2 \sigma_{2}{ }^{2} C_{2}+\sigma_{2} \omega^{0.5}}{\left(1+\omega^{0.5} \sigma_{2} C_{2}\right)^{2}+\omega^{2} C_{2}{ }^{2}\left(R_{\mathrm{ct} 2}+\sigma_{2} \omega^{-0.5}\right)^{2}}
\end{aligned}
$$

When $\omega$ tends to infinity, Equation (11) is simplified by Equations (9) and (10); it is a circular equation, with the abscissa foci at $\left(R_{\mathrm{s}}, 0\right)$ and $\left(R_{\mathrm{s}}+R_{\mathrm{ct} 1}+R_{\mathrm{ct} 2}, 0\right)$.

$$
\left[Z^{\prime}-R_{\mathrm{s}}-\frac{1}{2}\left(R_{\mathrm{ct} 1}+R_{\mathrm{ct} 2}\right)\right]^{2}+Z^{\prime \prime 2}=\left(\frac{R_{\mathrm{ct} 1}+R_{\mathrm{ct} 2}}{2}\right)^{2}
$$

The electrochemical impedance of each group of LCM specimens is as shown in Figure 9. The abscissa represents the real part of the complex impedance, the ordinate represents the imaginary part of the complex impedance, and the points in the figure are the values at different frequencies; There are complete impedance arcs in the Nyquist diagram of each group in the high-frequency band, while in the middle and low-frequency bands some impedance arcs may be seen in the Nyquist diagram, but only for specimens with 75\% (1:3) and 80\% (1:4) high-sulphur fly ash content. With the 
increase in the sodium sulphate concentration, the semicircle diameter in the Nyquist diagram of each group increased.

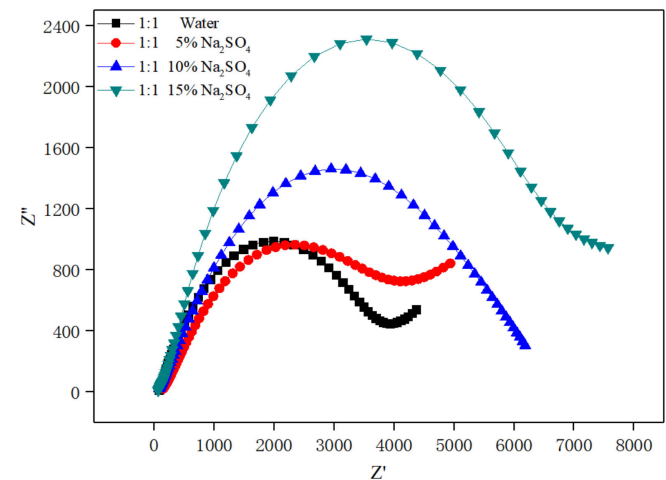

(a)

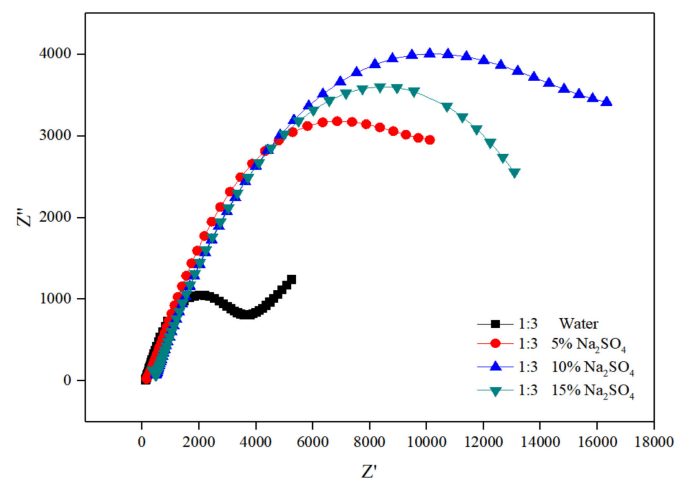

(c)

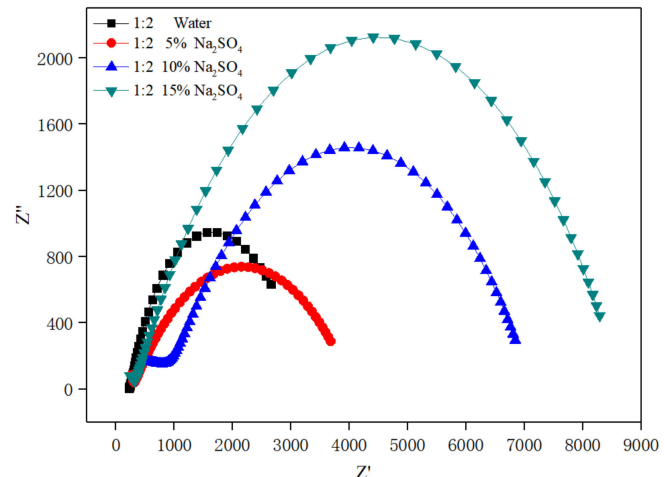

(b)

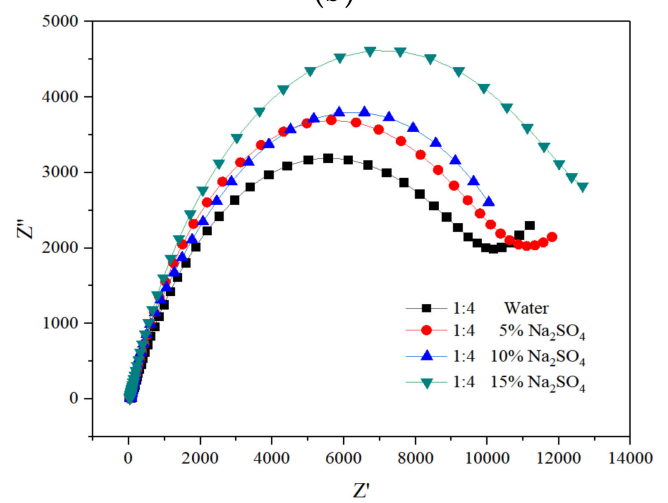

(d)

Figure 9. Nyquist at different high-sulphur fly ash contents. (a) $50 \%$ high-sulphur fly ash, (b) $66.7 \%$ high-sulphur fly ash, (c) 75\% high-sulphur fly ash, (d) 80\% high-sulphur fly ash.

The diameter of the high-frequency arc essentially reflects the process of charge transfer. As the concentration of sodium sulphate increases, ettringite crystals, which are difficult to dissolve in water, are generated. Corrosion products gradually fill the pores, while the decrease in pore diameter and porosity is not conducive to the migration of ions at the solid liquid interface. Thus, the charge transfer in the electrochemical system is blocked and the radius of the high-frequency arc is increased. With the increase in the proportion of high-sulphur fly ash in the mixture, the arc radius in the high-frequency band also increases. This is attributed to the adsorption of ions by fly ash, which increases the diffusion resistance of ions in porous solution and at the solid liquid interface. In addition, due to the large specific surface area of fly ash, it can fill small holes in the material, which renders the structure more compact and reduces its porosity. Therefore, the resistance increases with the increase in the high-sulphur fly ash content.

The electrochemical impedance spectroscopy of each group was further studied. Figure 10 demonstrates the variation of components $R_{\mathrm{s}}$ and $R_{\mathrm{ct} 1}$ with the concentration of sodium sulphate in each group.

Without sodium sulphate corrosion, the value of the $R_{\mathrm{S}}$ of high proportional high-sulphur fly ash content is larger than that of specimens containing lower amounts thereof. With the increase in the sodium sulphate concentration, the value of $R_{\mathrm{S}}$ of specimens with different high-sulphur fly ash contents decreases to varying degrees, especially at high proportional concentrations of high-sulphur fly ash. The material ion transfer resistance $R_{\mathrm{ct} 1}$ increases with the increasing sodium sulphate concentration and the higher the high-sulphur fly ash content, the faster the increase. 
This phenomenon can be explained as the filling and adsorption effect of fly ash on the internal structure. Fly ash reacts with the $\mathrm{CH}$ covering its surface and eventually precipitates pozzolanic products, which strengthens the connection between the fly ash particles and cement hydration products, densifies the overall structure, and leads to the increasing pore solution resistance. With the increase in the sodium sulphate concentration, sulphate ions penetrate the matrix, increasing the amount of strong electrolyte in the porous solution and enhancing the conductivity of the porous solution. Considering this, the resistance $R_{\mathrm{S}}$ of the porous solution decreases. On the other hand, the corrosion induced by the sodium sulphate also generates ettringite (with a low solubility), which is easily precipitated and stuck to the pore surface. With the increasing high-sulphur fly ash content, some $\mathrm{Al}^{3+}$ and $\mathrm{AlO}_{4}{ }^{5-}$ will be bound to C-S-H and other gel structures; however, some $\mathrm{Al}^{3+}$ dissociates in the pore solution and cement. Hydration products bind to new hydrated aluminates, and the intrusive $\mathrm{SO}_{4}{ }^{2-}$ reacts therewith to form $\mathrm{AFt}$, resulting in an increase in the difficulty of charge transfer. However, some $\mathrm{Al}^{3+}$ ions remain free in the porous solution and combine with cement hydration products to form new hydrated aluminates. The intrusive $\mathrm{SO}_{4}{ }^{2-}$ reacts therewith to form $\mathrm{AFt}$, which results in the greater hindrance of charge transfer (this is consistent with the performance evinced by the Nyquist plots).
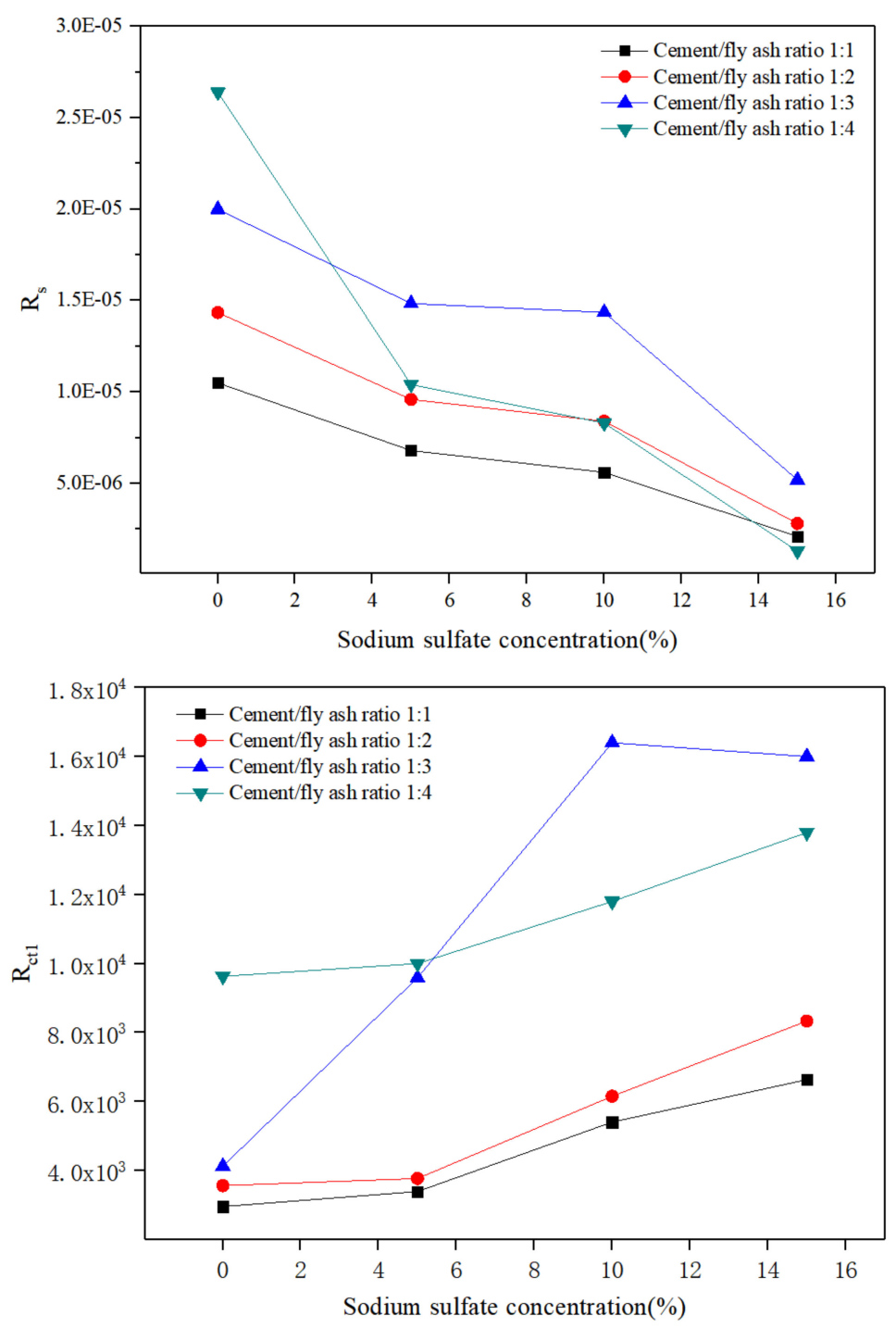

Figure 10. Effect of sodium sulphate concentration on components. 


\subsection{SEM Analysis}

Figure 11 shows the micro-morphology of specimens at different magnifications. Figure 11a illustrates a 30 -fold magnification view of the specimens containing 50\% high-sulphur fly ash. It can be observed that different sized bubbles are randomly distributed across the section. The arrangement and distribution of these bubbles change the density of the material; directly affect the strength; and indirectly improve its heat preservation, freeze resistance, and sound-insulation performance.

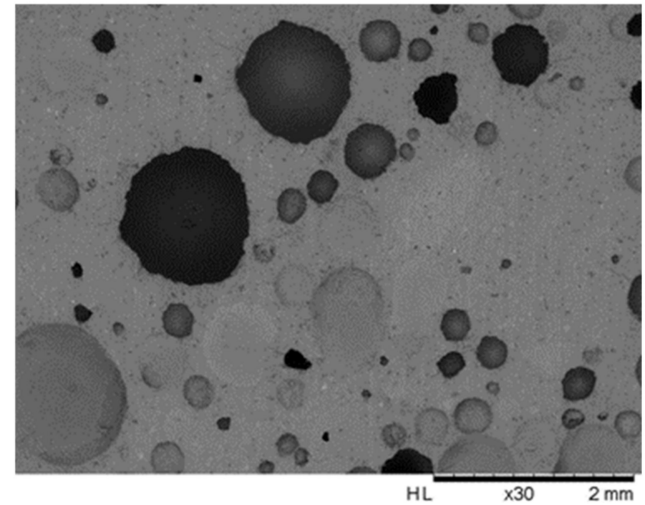

(a)

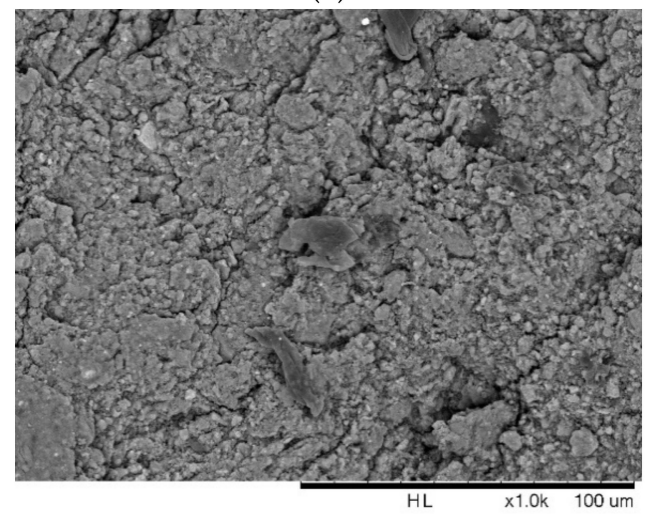

(c)

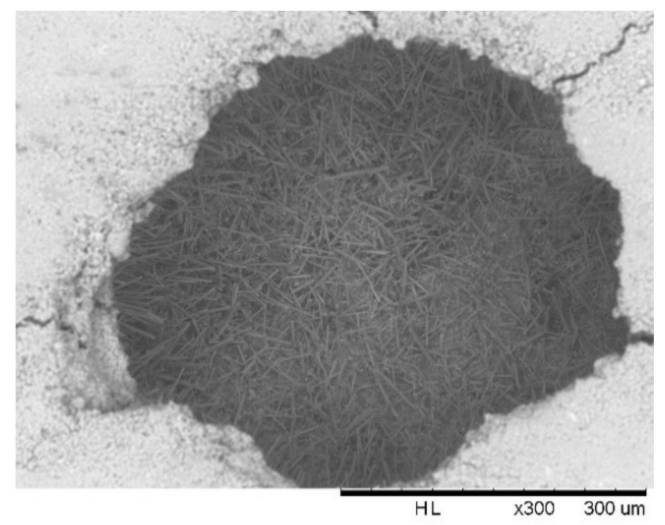

(e)

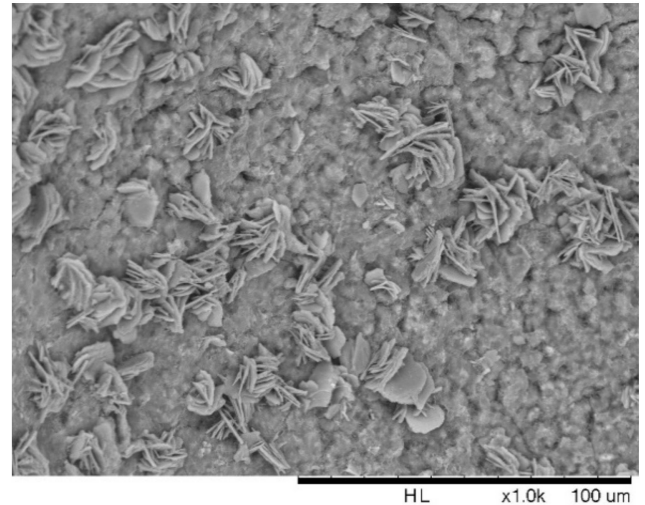

(b)

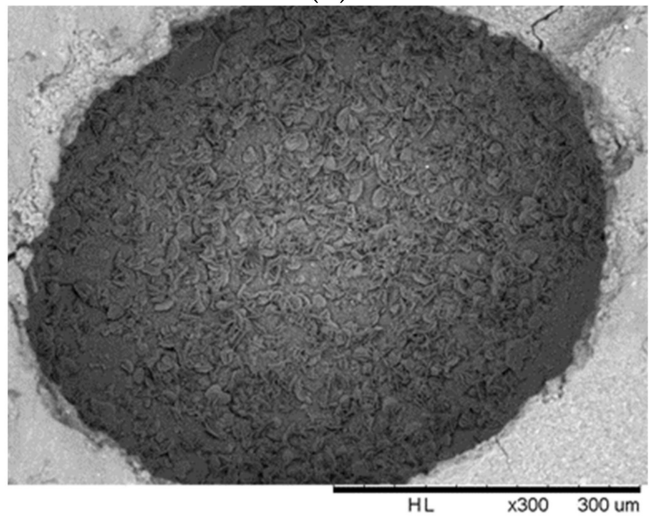

(d)

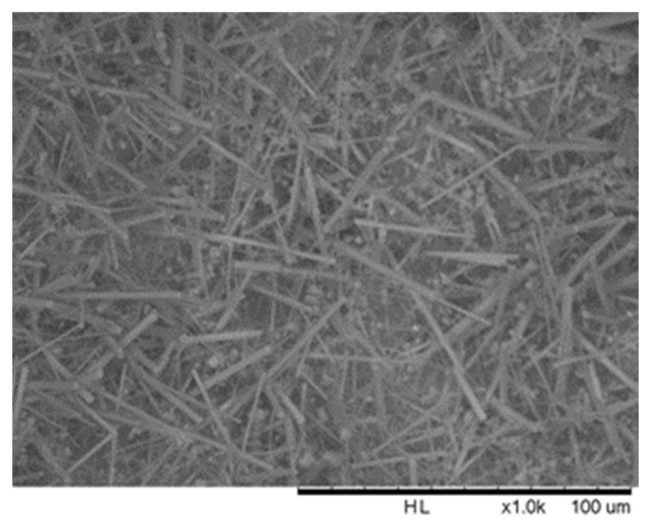

(f)

Figure 11. Micro-morphology of specimens of different mix designs. (a) $50 \%$ water environment $\times 30$;

(b) $50 \%$ water environment $\times 1000$; (c) $80 \%$ water environment $\times 1000$; (d) $50 \%$ water environment $\times 300$;

(e) $50 \%, 10 \%$ sodium sulphate $\times 300$; (f) $50 \%, 10 \%$ sodium sulphate $\times 1000$.

Figure $11 \mathrm{~b}$ shows a 1000-fold magnification view of the specimens with a high-sulphur fly ash content of $50 \%$ (1:1) cured in water. Each unit is agglomerated by C-S-H and CAH produced by cement 
hydration and the pozzolanic effect of fly ash; many plate-like or lamellar $\mathrm{CH}$ and $\mathrm{CaCO}_{3}$ components are consolidated by the surrounding structural units, resulting in the reduction in inter-cell porosity.

With the increase in the high-sulphur fly ash content to 80 (1:4), the voids between units are filled by fine fly ash particles, and the number of voids decreases; however, the cementitious components in materials are mainly provided by cement hydration products, and with the decrease in the cement content, the amount of cementitious substances decreases. In addition, since the $\mathrm{CH}$ required for the fly ash pozzolanic reaction is produced by cement hydration, the reduction in cement will also inhibit this pozzolanic effect, resulting in reduced contact strength and insufficient connection between units, as shown in Figure 11c.

Figure 11d shows a 300-fold magnification of the hole with a high-sulphur fly ash content of $50 \%$; the units in the holes are cemented tightly. When the samples are corroded by sodium sulphate, the long rod-like ettringite crystals grow densely from the pore wall, and the original holes are covered by the crystals, as shown in Figure 11e,f, indicating that the holes in LCMs can provide sufficient space for the growth of $\mathrm{AFt}$ and release the expansion pressure caused by crystal growth.

\section{Conclusions}

The surface of LCMs was corroded after curing in sodium sulphate solution. The greater the fly ash content, the greater the concentration of sodium sulphate, and the more severe the erosion.

High-sulphur fly ash has a negative effect on the structural strength of LCMs after corrosion, but when the fly ash content is less than $75 \%$, the effect of fly ash on the strength is small. The change in strength with changes in concentration of sodium sulphate shows that the LCMs have a certain degree of resistance to erosion induced by sodium sulphate.

The XRD diffraction data indicate that LCMs will produce corrosion products under attack by sodium sulphate, AFt crystals, and gypsum crystals; gypsum crystals are the main corrosion product formed under attack from high-concentration sodium sulphate solutions.

The electrochemical impedance spectroscopy and micro-morphology of LCMs show that a lower fly ash content is conducive to increasing the density of the structure. The pore structure in LCMs is able to provide space for the growth of AFt crystals and other corrosive substances, thus relieving the expansion pressure.

Author Contributions: X.W. and P.H. contributed to the conceptualization of the study; X.D. performed the supervision; X.L., X.B., B.H., S.N., and F.S. helped perform the formal analysis. X.W. performed the writing一 original draft. All authors have read and agreed to the published version of the manuscript.

Funding: This work was supported by the National Natural Science Foundation of China (Grant no. 41807256) and the Key Laboratory of Geotechnical and Underground Engineering of Ministry of Education, Tongji University (No. KLE-TJGE-B1701).

Acknowledgments: The author thanks the geotechnical Institute of civil engineering, Taiyuan University of technology for its support.

Conflicts of Interest: The authors declared that they have no conflicts of interest to this work. We declare that we do not have any commercial or associative interest that represents a conflict of interest in connection with the work submitted.

\section{References}

1. Chauhan, M.S.; Mittal, S.; Mohanty, B. Performance evaluation of silty sand subgrade reinforced with fly ash and fibre. Geotext. Geomembr. 2008, 26, 429-435. [CrossRef]

2. Phetchuay, C.; Horpibulsuk, S.; Suksiripattanapong, C.; Chinkulkijniwat, A.; Arulrajah, A.; Disfani, M.M. Calcium carbide residue: Alkaline activator for clay-fly ash geopolymer. Constr. Build. Mater. 2014, 69, 285-294. [CrossRef]

3. Kua, T.-A.; Arulrajah, A.; Horpibulsuk, S.; Du, Y.-J.; Shen, S.-L. Strength assessment of spent coffee grounds-geopolymer cement utilizing slag and fly ash precursors. Constr. Build. Mater. 2016, 115, 565-575. [CrossRef] 
4. Wei, H.; Jiao, Y.; Liu, H. Effect of freeze-thaw cycles on mechanical property of silty clay modified by fly ash and crumb rubber. Cold Reg. Sci. Technol. 2015, 116, 70-77. [CrossRef]

5. Kua, T.-A.; Arulrajah, A.; Mohammadinia, A.; Horpibulsuk, S.; Mirzababaei, M. Stiffness and deformation properties of spent coffee grounds based geopolymers. Constr. Build. Mater. 2017, 138, 79-87. [CrossRef]

6. Jiang, N.-J.; Du, Y.-J.; Liu, K. Durability of lightweight alkali-activated ground granulated blast furnace slag (GGBS) stabilized clayey soils subjected to sulfate attack. Appl. Clay Sci. 2018, 161, 70-75. [CrossRef]

7. Solanki, P.; Zaman, M.M. Laboratory Performance Evaluation of Subgrade Soils Stabilized with Sulfate-Bearing Cementitious Additives. J. Test. Eval. 2010, 38, 1-12.

8. Knopp, J.; Moormann, C. Ettringite Swelling in the Treatment of Sulfate-Containing Soils Used as Subgrade for Road Constructions. Procedia Eng. 2016, 143, 128-137.

9. Islam, M.A.; Golrokh, A.J.; Lu, Y. Chemomechanical Modeling of Sulfate Attack-Induced Damage Process in Cement-Stabilized Pavements. J. Eng. Mech. 2019, 145. [CrossRef]

10. Zhang, W.; Zhang, Y.; Gao, L. Effect of low-calcium fly ash on sulfate resistance of cement paste under different exposure conditions. Adv. Concr. Constr. 2019, 7, 175-181.

11. Neramitkornburi, A.; Horpibulsuk, S.; Shen, S.L.; Chinkulkijniwat, A.; Arulrajah, A.; Disfani, M.M. Durability against wetting-drying cycles of sustainable Lightweight Cellular Cemented construction material comprising clay and fly ash wastes. Constr. Build. Mater. 2015, 77, 41-49. [CrossRef]

12. Neramitkornburi, A.; Horpibulsuk, S.; Shen, S.L.; Arulrajah, A.; Disfani, M.M. Engineering properties of lightweight cellular cemented clay-fly ash material. Soils Found. 2015, 55, 471-483. [CrossRef]

13. Rasheed, M.A.; Prakash, S.S. Behavior of hybrid-synthetic fiber reinforced cellular lightweight concrete under uniaxial tension-Experimental and analytical studies. Constr. Build. Mater. 2018, 162, 857-870. [CrossRef]

14. Huang, J.-J.; Su, Q.; Zhao, W.-H.; Li, T.; Zhang, X.-X. Experimental study on use of lightweight foam concrete as subgrade bed filler of ballastless track. Constr. Build. Mater. 2017, 149, 911-920. [CrossRef]

15. Kim, Y.T.; Kim, H.J.; Lee, G.H. Mechanical behavior of lightweight soil reinforced with waste fishing net. Geotext. Geomembr. 2008, 26, 512-518. [CrossRef]

16. Kraemer, C.; Schauerte, M.; Kowald, T.L.; Trettin, R.H.F. Three-phase-foams for foam concrete application. Mater. Charact. 2015, 102, 173-179. [CrossRef]

17. She, W.; Du, Y.; Zhao, G.; Feng, P.; Zhang, Y.; Cao, X. Influence of coarse fly ash on the performance of foam concrete and its application in high-speed railway roadbeds. Constr. Build. Mater. 2018, 170, 153-166. [CrossRef]

18. Amran, Y.H.M.; Farzadnia, N.; Ali, A.A.A. Properties and applications of foamed concrete; A review. Constr. Build. Mater. 2015, 101, 990-1005. [CrossRef]

19. Kadela, M.; Kozłowski, M.; Kukiełka, A. Application of Foamed Concrete in Road Pavement-Weak Soil System. Procedia Eng. 2017, 193, 439-446. [CrossRef]

20. Kang, S.-H.; Jeong, Y.; Kim, M.O.; Moon, J. Pozzolanic reaction on alkali-activated Class F fly ash for ambient condition curable structural materials. Constr. Build. Mater. 2019, 218, 235-244. [CrossRef]

21. Wang, T.; Ishida, T. Multiphase pozzolanic reaction model of low-calcium fly ash in cement systems. Cem. Concr. Res. 2019, 122, 274-287. [CrossRef]

22. Gadouri, H.; Harichane, K.; Ghrici, M. Assessment of sulphates effect on $\mathrm{pH}$ and pozzolanic reactions of soil-lime-natural pozzolana mixtures. Int. J. Pavement Eng. 2019, 20, 761-774. [CrossRef]

23. Kan, L.; Zhang, L.; Shi, H. Hydration Kinetics of Municipal Solid Wastes Incineration (MSWI) Fly Ash-Cement. J. Wuhan Univ. Technol. -Mater. Sci. Ed. 2019, 34, 596-603. [CrossRef]

24. Liao, W.; Sun, X.; Kumar, A.; Sun, H.; Ma, H. Hydration of Binary Portland Cement Blends Containing Silica Fume: A Decoupling Method to Estimate Degrees of Hydration and Pozzolanic Reaction. Front. Mater. 2019, 6. [CrossRef]

25. Ramanathan, S.; Moon, H.; Croly, M.; Chung, C.-W.; Suraneni, P. Predicting the degree of reaction of supplementary cementitious materials in cementitious pastes using a pozzolanic test. Constr. Build. Mater. 2019, 204, 621-630. [CrossRef]

26. Contrafatto, L. Recycled Etna volcanic ash for cement, mortar and concrete manufacturing. Constr. Build. Mater. 2017, 151, 704-713. [CrossRef]

27. Contrafatto, L.; Danzuso, C.L.; Gazzo, S.; Greco, L. Physical, mechanical and thermal properties of lightweight insulating mortar with recycled Etna volcanic aggregates. Constr. Build. Mater. 2020, 240, 117917. [CrossRef] 
28. Xiao, H.; Zhang, F.; Liu, R.; Zhang, R.; Liu, Z.; Liu, H. Effects of pozzolanic and non-pozzolanic nanomaterials on cement-based materials. Constr. Build. Mater. 2019, 213, 1-9. [CrossRef]

29. Pourkhorshidi, A.R.; Najimi, M.; Parhizkar, T.; Jafarpour, F.; Hillemeier, B. Applicability of the standard specifications of ASTM C618 for evaluation of natural pozzolans. Cem. Concr. Compos. 2010, 32, 794-800. [CrossRef]

30. Celik, K.; Hay, R.; Hargis, C.W.; Moon, J. Effect of volcanic ash pozzolan or limestone replacement on hydration of Portland cement. Constr. Build. Mater. 2019, 197, 803-812. [CrossRef]

31. Zhao, Y.; Gao, J.; Liu, C.; Chen, X.; Xu, Z. The particle-size effect of waste clay brick powder on its pozzolanic activity and properties of blended cement. J. Clean. Prod. 2020, 242, 118521. [CrossRef]

32. Kupwade-Patil, K.; Palkovic, S.D.; Bumajdad, A.; Soriano, C.; Büyüköztürk, O. Use of silica fume and natural volcanic ash as a replacement to Portland cement: Micro and pore structural investigation using NMR, XRD, FTIR and X-ray microtomography. Constr. Build. Mater. 2018, 158, 574-590. [CrossRef]

33. Kalakada, Z.; Doh, J.H.; Zi, G. Utilisation of coarse glass powder as pozzolanic cement-A mix design investigation. Constr. Build. Mater. 2020, 240, 117916. [CrossRef]

34. Hossain, K.M.A.; Lachemi, M. Performance of volcanic ash and pumice based blended cement concrete in mixed sulfate environment. Cem. Concr. Res. 2006, 36, 1123-1133. [CrossRef]

35. Puthipad, N.; Ouchi, M.; Attachaiyawuth, A. Effects of fly ash, mixing procedure and type of air-entraining agent on coalescence of entrained air bubbles in mortar of self-compacting concrete at fresh state. Constr. Build. Mater. 2018, 180, 437-444. [CrossRef]

36. Chen, X.; Yan, Y.; Liu, Y.; Hu, Z. Utilization of circulating fluidized bed fly ash for the preparation of foam concrete. Constr. Build. Mater. 2014, 54, 137-146. [CrossRef]

37. Jones, M.R.; McCarthy, A. Utilising unprocessed low-lime coal fly ash in foamed concrete. Fuel 2005, 84, 1398-1409. [CrossRef]

38. Posi, P.; Ridtirud, C.; Ekvong, C.; Chammanee, D.; Janthowong, K.; Chindaprasirt, P. Properties of lightweight high calcium fly ash geopolymer concretes containing recycled packaging foam. Constr. Build. Mater. 2015, 94, 408-413. [CrossRef]

39. Gokce, H.S.; Hatungimana, D.; Ramyar, K. Effect of fly ash and silica fume on hardened properties of foam concrete. Constr. Build. Mater. 2019, 194,1-11. [CrossRef]

40. Falliano, D.; de Domenico, D.; Ricciardi, G.; Gugliandolo, E. Experimental investigation on the compressive strength of foamed concrete: Effect of curing conditions, cement type, foaming agent and dry density. Constr. Build. Mater. 2018, 165, 735-749. [CrossRef]

41. Hussin, M.W.; Muthusamy, K.; Zakaria, F. Effect of Mixing Constituent toward Engineering Properties of POFA Cement-Based Aerated Concrete. J. Mater. Civ. Eng. 2010, 22, 287-295. [CrossRef]

42. Chindaprasirt, P.; Rattanasak, U. Shrinkage behavior of structural foam lightweight concrete containing glycol compounds and fly ash. Mater. Des. 2011, 32, 723-727. [CrossRef]

43. Ma, C.; Chen, B. Experimental study on the preparation and properties of a novel foamed concrete based on magnesium phosphate cement. Constr. Build. Mater. 2017, 137, 160-168. [CrossRef]

44. Jones, M.R.; McCarthy, A. Heat of hydration in foamed concrete: Effect of mix constituents and plastic density. Cem. Concr. Res. 2006, 36, 1032-1041. [CrossRef]

45. Farhan, N.A.; Sheikh, M.N.; Hadi, M.N.S. Investigation of engineering properties of normal and high strength fly ash based geopolymer and alkali-activated slag concrete compared to ordinary Portland cement concrete. Constr. Build. Mater. 2019, 196, 26-42. [CrossRef]

46. Uthaman, S.; Vishwakarma, V.; George, R.P.; Ramachandran, D.; Kumari, K.; Preetha, R.; Premila, M.; Rajaraman, R.; Mudali, U.K.; Amarendra, G. Enhancement of strength and durability of fly ash concrete in seawater environments: Synergistic effect of nanoparticles. Constr. Build. Mater. 2018, 187, 448-459. [CrossRef]

47. Li, J.; Ji, Y.; Zhang, L.; Liu, B. Resistance to sulfate attack of magnesium phosphate cement-coated concrete. Constr. Build. Mater. 2019, 195, 156-164.

48. Sirisawat, I.; Baingam, L.; Saengsoy, W.; Krammart, P.; Tangtermsirikul, S. Sodium and Magnesium Sulfate Resistance of Mortars with Interground Limestone and Limestone Powder Replacing Cements. J. Adv. Concr. Technol. 2014, 12, 403-412. [CrossRef]

49. Li, J.; Ji, Y.; Huang, G.; Zhang, L. Microstructure Evolution of a Magnesium Phosphate Protective Layer on Concrete Structures in a Sulfate Environment. Coatings 2018, 8, 140. [CrossRef] 
50. Tixier, R.; Mobasher, B. Modeling of Damage in Cement-Based Materials Subjected to External Sulfate Attack. II: Comparison with Experiments. J. Mater. Civ. Eng. 2003, 15, 314-322. [CrossRef]

51. Haufe, J.; Vollpracht, A. Tensile strength of concrete exposed to sulfate attack. Cem. Concr. Res. 2019, 116, 81-88. [CrossRef]

52. Siad, H.; Kamali-Bernard, S.; Mesbah, H.A.; Escadeillas, G.; Mouli, M.; Khelafi, H. Characterization of the degradation of self-compacting concretes in sodium sulfate environment: Influence of different mineral admixtures. Constr. Build. Mater. 2013, 47, 1188-1200. [CrossRef]

53. Sun, H.; Ren, Z.; Memon, S.A.; Zhao, D.; Zhang, X.; Li, D.; Xing, F. Investigating drying behavior of cement mortar through electrochemical impedance spectroscopy analysis. Constr. Build. Mater. 2017, 135, 361-368. [CrossRef]

54. Zhu, Y.; Zhang, H.; Zhang, Z.; Yao, Y. Electrochemical impedance spectroscopy (EIS) of hydration process and drying shrinkage for cement paste with W/C of 0.25 affected by high range water reducer. Constr. Build. Mater. 2017, 131, 536-541. [CrossRef]

55. Dong, B.; Li, G.; Zhang, J.; Liu, Y.; Xing, F.; Hong, S. Non-destructive tracing on hydration feature of slag blended cement with electrochemical method. Constr. Build. Mater. 2017, 149, 467-473. [CrossRef]

56. Dong, B.; Gu, Z.; Qiu, Q.; Liu, Y.; Ding, W.; Xing, F.; Hong, S. Electrochemical feature for chloride ion transportation in fly ash blended cementitious materials. Constr. Build. Mater. 2018, 161, 577-586. [CrossRef]

(C) 2020 by the authors. Licensee MDPI, Basel, Switzerland. This article is an open access article distributed under the terms and conditions of the Creative Commons Attribution (CC BY) license (http://creativecommons.org/licenses/by/4.0/). 